MANCHESTER

1824

군

Economics

Discussion Paper Series

EDP-1216

Risk premia in multi-national enterprises

Stefan Lutz

September 2012

Economics

School of Social Sciences

The University of Manchester

Manchester M13 9PL 


\title{
Risk premia in multi-national enterprises *
}

\author{
Stefan Lutz \\ University of Manchester, ICAE, ICER, I.R.E.F.**
}

The CAPM implies that investors require equity risk premia when choosing risky investments and therefore demand higher returns to equity invested if higher risk is present. This should apply to investments in independent enterprises and multi-national enterprises alike. This hypothesis is investigated by analyzing a panel of 407,000 European firms for the years 1985 to 2010. When income is set in relation to invested capital, risk measured by earnings volatility emerges as the most important stable determinant of income. Results indicate that both MNEs and independent firms regularly account for risk as a major determinant of income when pricing international goods and services. Hence international taxation rules for multi-national enterprises should account for risk premia in transfer prices and resulting profits.

JEL classification: G0, F2, M4

Keywords: MNE, firm valuation, DCF, CAPM, risk premium, transfer pricing

\footnotetext{
* The views expressed in this paper are those of the author and do not necessarily reflect those of the institutions he is affiliated with. The author would like to thank Stephen Blough, Clark Chandler, Shawkat Hammoudeh, Michael McAleer, Teodosio Perez Amaral and a referee for helpful comments and suggestions as well as Keshav Goel and Nitish Maini for diligent research assistance. Financial support by the International Centre for Economic Research (ICER), Torino, Italy, and by the Spanish Ministry of Education and Science (Grant No. ECO2008-06191) is gratefully acknowledged.

** Contact details: stefan.lutz@manchester.ac.uk, T. +49 173 576 4013, F. +49 1802119912111.
} 


\section{Introduction}

The question what determines the size of firm's profits of multi-national enterprises - in fact of firms in general - can be approached from two sides. On the one hand, profits reflect a firm's ability to capture markets and deliver value that is remunerated by customers. From the point of view of the investor financing a particular firm; this may be called the "income" or "production" view. On the other hand, the same investor may ask whether he is adequately compensated for providing the capital necessary to operate the firm; this may be called the "cost-of-capital" view. With well-functioning capital markets, both views should arrive at similar results regarding the size of a firm's profits. In fact, the latter "cost-of-capital" view has its theoretical foundation in the well-known Capital Asset Pricing Model (CAPM).

The CAPM implies that investors take risk into account when choosing an investment investors require an equity risk premia if the investment is risky. Capital market data confirms that empirical equity risk premia are increasing in the volatility of the return. This should also apply to equity investment in individual firms - hence investors should require higher profits as return to equity invested if higher risk is present. The hypothesis follows that investors will ask for risk premia when investing in independent enterprises and in multi-national enterprises alike. Hence expected profits are mainly a function of the amount of investment necessary (size of capital employed) and the risk expected to be attached to the firm's operations - in other words: return on invested capital is mainly a function of investment risk.

This research presents evidence that this is in fact the case by identifying determinants of actual ex-post enterprise profits; the results obtained indicate that risk measured by earnings volatility is the most important determinant of income when income is set in relation to invested capital. Data analyzed comes from the Amadeus firm-level data base as well as from Thomson/Reuter and spans a panel of 407,000 European firms for the years 1985 to 2010.

The remainder of the paper is structured as follows. Section 2 introduces the economic and 
institutional background, the resulting research questions posed here, as well as the hypotheses to be investigated. The underlying theory is presented in Section 3. Section 4 describes the data used. Section 5 presents the general modeling and summarizes the results. Section 6 concludes. Statistical and econometric results are presented in the appendix.

\section{Background and research questions}

A firm's profitability in the presence of risk can be assessed by the entrepreneur by taking the amount of risk into account when considering the return on capital invested. Given the risk present in its operations, the firm should earn an individual equity risk premium (ERP) and such a premium can be derived with recourse to the CAPM. ${ }^{1}$

One of the main conclusions of the CAPM theory is that an adequate remuneration for the risks assumed by an equity investment is given by the market risk premium multiplied by the covariance of the returns on the equity invested with the market return.

Since that covariance contains a measure of the volatility of the returns on the equity invested, an adequate equity risk premium (ERP) is also a function of the volatility of the returns on the equity invested. In fact, empirical analyses using historical financial markets data show that the ERP paid by the capital market for the assumption of risk corresponds to a multiple of the standard deviation of the Returns on Equity $(\mathrm{RoE}){ }^{2}$

While these empirical results are derived from data on investments in financial markets, the same principles should also apply when an investor finances an enterprise directly. As a consequence, the pricing of an enterprise's products should be set such that the resulting profits can be expected to adequately remunerate the firm's equity investors for the risks they

\footnotetext{
${ }^{1}$ See Sharpe (1964), Treynor (1962), Lintner (1965), Mossin (1966), and Markowitz (1959). For more recent discussions see, e.g., Perold (2004), Fama/French (2004). For a multi-period extension, see Fama (1977).

${ }^{2}$ See, e.g., Damodaran (2008), Damodaran (2010).
} 
have taken in financing the enterprise. Recent research shows that this is in fact the case and that firm's average RoEs tend to increase with the volatility of those RoEs. ${ }^{3}$

Consequently, this research aims to identify major determinants of firm profits from empirical firm-level data. In particular, the determinants of profits measured as returns to equity or alternative measures of capital invested are explored. Furthermore, the role of an individual firm's return volatility relative to other determinants is investigated. Lastly, conclusions are drawn with respect to adequate determination of profit comparables for transfer-pricing purposes. Taxation of MNEs within a national jurisdiction relies on transfer pricing to determine the taxable profit of a national subsidiary by comparing it to profits of hypothetically comparable independent firms. OECD transfer pricing guidelines stipulate that the pricing of these transactions and the resulting profits must be such that uncontrolled third parties would have agreed voluntarily to undertake such transactions; this is known as the arm's length standard. In principle this implies that prices for goods and services are set at market prices and that profits should earn a market return that adequately remunerates individual risk. Further implications for transfer-price related valuation of firms and/or assets are discussed also. ${ }^{4}$

\section{Theoretical Basis}

When the CAPM is applied to equity investment in individual firms, the discounted cash flow method $^{5}$ (DCF) is frequently used for the valuation of that firm's equity and even for the valuation of individual firm assets. Since DCF consists of discounting future cash earnings, an appropriate discount rate needs to be applied. The discount rate represents the (opportunity) cost

\footnotetext{
3 See Lutz/Kleinfeldt (2012) who analyzed a panel of about 160,000 firms for the years 1992 to 2007.

${ }^{4}$ See OECD transfer pricing guidelines (1995/2001/2010), in particular Para 1.6, 1.12, 1.27 and Chapters IX and VI; downloaded at http://www.oecd.org/document/34/0,3746,en_2649 $33753 \quad 1915490 \quad 1 \quad 1 \_1 \_1,00 . h t m l$.

${ }^{5}$ See, e.g., Brealey/Myers/Allen (2006) chapters 4 or 8, Luenberger (1998) chapter 7 for an introduction.
} 
of capital invested; if the cash flows valued are those accruing to equity (FCFE), i.e. after deduction of any costs of debt financing, then the discount rate represents the cost of equity financing or the required (minimum) expected RoE. ${ }^{6}$

This RoE consists of the sum of the risk-free rate of interest and the ERP which can be derived with recourse to the CAPM. According to the standard convention in the CAPM, the required return for any asset $\mathrm{i}, \mathrm{r}_{\mathrm{i}}$, can be expressed as:

(1) $\quad r_{i}=r_{f}+\beta_{i}\left(r_{m}-r_{f}\right)$ and

$$
\beta_{i}=\frac{\sigma_{i m}}{\sigma_{m}^{2}}=\frac{\rho_{i m} \sigma_{i} \sigma_{m}}{\sigma_{m}^{2}}
$$

where $r_{f}$ denotes the risk-free rate of interest, $r_{m}$ denotes the market return, $\sigma_{\text {im }}$ and $\rho_{\text {im }}$ denote the covariance and the correlation coefficient, respectively, between firm i's return on equity and the market return, $\sigma_{\mathrm{i}}$ denotes the standard deviation of asset i's return, $\sigma_{\mathrm{m}}$ denotes the standard deviation of the market return, and $\sigma_{m}^{2}$ denotes the variance of the market return.

Suppose asset $\mathrm{i}$ is a particular firm financed with a debt to equity ratio of $\delta$ and taxed at rate $\tau$, then equation (2) becomes

$$
\beta_{i}=\left(1+(1-\tau) \delta_{i}\right) \frac{\rho_{i m} \sigma_{i} \sigma_{m}}{\sigma_{m}^{2}}
$$

According to Modigliani/Miller (1958), equation (2) denotes the pure investment risk (captured by the "asset beta") whereas equation (2') also captures the additional financing risk due to debt financing. Note that while volatility is a significant determinant of returns, the market correlation $\rho_{\mathrm{im}}$ is typically not significant. This has been shown repeatedly in capitalmarket studies and also seems to hold with enterprise data. ${ }^{7}$ Taking this into account and treating the market return volatility as given, we can define $\alpha_{\mathrm{i}}$ as:

\footnotetext{
${ }^{6}$ FCFE is widely used and can be particularly useful for the valuation of firms with varying gearing (debt/equity financing) ratios. See, e.g., Shaw (2007), p. 15.

${ }^{7}$ See Lutz/Kleinfeldt (2012).
} 
(3) $\quad \alpha_{i}=\left(1+(1-\tau) \delta_{i}\right) \frac{\rho_{i m}}{\sigma_{m}}\left(r_{m}-r_{f}\right)$.

For the firm $i$, let $\mathrm{C}_{\mathrm{i}}$ be its contemporary FCFE, $\mathrm{r}_{\mathrm{i}}$ its required return on equity (the applicable discount rate), and $g_{i}$ the expected growth rate of $C_{i}$. Firm i's market value of equity will then be given by $\mathrm{V}_{\mathrm{i}}$ :

(4) $\quad V_{i}=\frac{C_{i}}{\left(r_{i}-g_{i}\right)}$

Furthermore, let $\sigma_{\mathrm{Ci}}$ be the standard deviation of $\mathrm{C}_{\mathrm{i}}$ then the required return on equity can be expressed as

$$
r_{i}=r_{f}+\alpha_{i} \sigma_{i} \quad \text { where } \quad \text { (6) } \quad \sigma_{i}=\sigma_{C i}\left(\frac{1}{V_{i}}\right)
$$

If the risk characteristics, i.e. the volatility, of the underlying asset changes, e.g. due to a functional change of a subsidiary within a multi-national enterprise, then the applicable discount rate will have to be adjusted. For a change of the volatility of the underlying asset from $\sigma_{0}$ to $\sigma_{1}$ all other things being equal, $\beta_{\mathrm{i}}$ changes from $\beta_{0}$ to $\beta_{1}$ as shown here:

$$
\beta_{1}=\frac{\sigma_{1} \rho_{1 m}}{\sigma_{0} \rho_{0 m}} \beta_{0}
$$

and the return on equity becomes:

$$
r_{1}=r_{f}+\beta_{1}\left(r_{m}-r_{f}\right)
$$

In principle, the derivation of $\beta$ in CAPM implies using $\sigma_{i}$ of the (de-trended) returns to market values of equity. If the relation between market equity values and book equity values is stable in the long run, the relationship between risk premium and volatility will also hold for the volatility of returns on book values of equity; empirically this seems to hold true. 


\section{The Data}

The empirical analysis is based on firm-level data from Bureau van Dijk's AMADEUS database and from Thomson Reuters Mutual Funds Holding (s12 Master File data); these data have been provided by Wharton Research Data Services (WRDS) as well as directly by Bureau van Dijk. In addition, data on US and European stock and bond markets as well as on macroeconomic indicators have been assembled from a variety of sources. A full list of data sources utilized and data obtained is given in Table 1 in the appendix. A full list of variables used is given in Table 2 in the appendix. Summary statistics are provided in Table 3.1.

The latest Amadeus database version (available through WRDS) contains financial data (profit and loss statement and balance sheet data) for more than 407,000 companies; the corresponding data for the years 1985 to 2010 (between 1 and ten years; 5.5 years on average) were downloaded and compiled in July 2011. Of these companies about 8500 are publicly listed and data on enterprise values are available for these firms for 4.5 years on average. In addition, data on stock prices and shares from Thomson Reuters are available for about 2800 of the publicly listed companies and for the same years (4.2 years on average).

Amadeus data collected includes in particular the following variables: company identification (name, BvD ID number, ticker, address etc.), trade and activities descriptions, industry codes (NACE 1.1 and 2, NAICS 2002), shareholder information, year of incorporation, number of employees, profit/loss data (revenue, cost of goods sold, operating cost, EBIT, etc.), balance sheet data (total assets, working capital, shareholders funds, etc., cash flow, enterprise value, liquidity and financing ratios, and return on shareholder funds. Thomson Reuters data collected includes in particular share prices and numbers of shares outstanding.

The data allow for analyses of several return measures. Besides returns on shareholder funds measures based on book values include returns on capital employed and on total assets. Market 
value measures include returns on enterprise value and on market capitalization, both measured in profits after taxes as well as in cash flows, as well as percentage changes in share prices.

Firms' trade and activities descriptions as well as their industry codes were screened in order to generate indicator (dummy) variables for the functions manufacturing, wholesale, retail, and service, activities. Shareholder and independence variables were screened to create an independence indicator (dummy) variable according to customary benchmark selection criteria. Further dummy variables were created per country, year, and consolidation code.

Data on general macroeconomic developments and climate were taken from the Ifo Institute's collection of European economic indices as well as from Eurostat via the European Central Bank. These comprise indices for European economic climate, European capacity utilization, and European production.

Data on US and European stock market and bond market returns were taken from Damodaran (2010), from ECB, Bundesbank and CESifo websites, and from Bloomberg. These comprise the S\&P 500 and the MSCI Europe stock market indices, 6-month US treasury bills, 10-year US treasury bonds, and generic Euro-area 10-year and 3-months government benchmark bonds.

\section{Modeling and results}

Given the panel data available, we can use the following generalized regression model to investigate the economic hypotheses presented:

$$
y_{i, t}=\alpha+\mathrm{B} F_{i}+\Gamma G_{i, t}+\Delta M_{t}+\varepsilon_{i, t}+\eta_{i}
$$

where the dependent variable $y_{i, t}$ is a profit level indicator (e.g. profits after taxes or return on shareholder funds) of company $i$ in period $t ; F_{i}$ is a vector of determinants specific to firm i but invariant over time (such as country, industry, functions performed, date incorporated); 
$G_{i, t}$ is a vector of determinants that may vary between firms and also over time (e.g., material costs, working capital, income volatility); $M_{t}$ is a vector of period-specific determinants outside of a particular firm (e.g. global economic factors and market indicators); $\varepsilon_{i, t}$ is an idiosyncratic error term that may vary between firms and also over time and is independently distributed with $\mathrm{E}\left(\varepsilon_{i, t}\right)=0$; and $\eta_{i}$ represents unobserved heterogeneity across firms, i.e., a company specific random effect that is independently distributed.

This general specification allows for either random-effects or fixed-effects modeling, where the random or fixed effects are firm-specific components. The more general approach is to allow for random firm-specific effects; the case where these effects are fixed, that is determinate constants instead of random variables, is a special sub-case. The data available contains several firm-specific, time-invariant variables that can be assumed to capture a significant part of present fixed effects (e.g. country, industry indicators, functional dummies, etc.). Hence a random-effects specification seems to be a priori more appropriate. Therefore, the majority of results presented are based on random-effects estimations.

In order to test the hypotheses introduced in Section 2, several sets of regressions are run. The first set of regressions in Models $\left(1 .^{*}\right)$ presents a first overview with several simple pooled OLS regressions. The second set of regressions in Models $\left(2 .^{*}\right)$ analyses profit variables $(c f)$ while the third set of regressions in Models $\left(3 .^{*}\right)$ and $\left(4 .^{*}\right)$ analyzes capital-return variables (rshf). Since the various profitability indicators are positively correlated with each other ${ }^{8}$, the results presented within these models are generally robust to some degree regardless of the profitability indicators chosen. Thus OLS specification of Model (4.1.1) is given by:

$$
\operatorname{avg} 3 c f_{i t}=\alpha+\gamma_{1} s t d 3 c f_{i t}+\varepsilon_{i t}
$$

\footnotetext{
${ }^{8}$ See Table 3.2 in the appendix for correlation coefficients of various profit and return on capital variables.
} 
The random-effects specification of Model (4.2.3) is given by:

$$
\operatorname{avg} 3 c f_{i t}=\alpha+\gamma_{1} s t d 3 c f_{i t}+\eta_{i}+\varepsilon_{i t}
$$

The fixed-effects specification of Model (4.3.3) is then given by:

$$
\operatorname{avg} 3 r s h_{i t}=\alpha+\beta_{i}+\gamma_{1} \operatorname{std} 3 r s h f_{i t}+\varepsilon_{i t}
$$

The instrumental-variables random-effects specification of Model (4.4.3) is then given by:

(13.a) $\quad \operatorname{avg} 3 r s h f_{i t}=\alpha+\gamma_{1} \operatorname{std} 3 r s h f+\gamma_{2} t \operatorname{shf}+\eta_{i}+\varepsilon_{i t}$

(13.b) $\quad \operatorname{std}_{3} r s h f_{i t}=\alpha+\gamma_{1}{\text { std } 3 r t a s_{i t}}+\gamma_{2} t s h f+\varepsilon_{i t}$

where the variable std3rshf in equation (13.a) is instrumented using std3rtas in equation (13.b). The other models are set up accordingly. The results of all model regressions are summarized in Tables reported 4.1, 4.2, 4.3 and 4.4 in the appendix. The prefix "avg3" denotes a 3-year moving average whereas "std3" denotes a 3-year moving standard deviation. Both variables are designed to capture the "longer-term" relationship between risk and profit or return, respectively.

The simple OLS regressions reported in Table 4.1 (in the appendix) give a first impression of the results. These results basically indicate that about half of profits may be explained by volatility measures regardless of whether profits are measured as cash flow, return to shareholder funds, or return to total assets.

Table 4.2 summarizes results on profit variables for several pooled OLS, fixed effects and random effects regressions. They basically confirm that risk measured as 3-year moving standard deviation has a strong significant effect on cash flows (measured as 3-year moving averages). Given the high correlations with other profit measures (reported in Table 3.2), these results are also true for these other profit variables. Model (4.2.1) presents a pooled OLS regression that includes a large number of potentially influential factors in the estimation. 
Besides volatility, operational size (operating revenue), financing (gearing ratio), only two functional indicators and two country indicators are significant determinants of cash flow levels. In alternative estimations, many other variables are insignificant or have been dropped due to collinearity.

These results seem to indicate the most variables besides volatility have comparatively little to add in explaining profits. The other three models presented in Table 4.2. are one fixed effects and two random effects specifications with most variables besides a volatility measure dropped. As shown by their R-squared values, they seem to indicate that volatility accounts for at least 50 percent of profits in any specification chosen. In fact this pattern is repeated in the fixed effects, random effects, and instrumental variables estimations for returns on shareholder funds presented in Tables 4.3. and 4.4.

The random-effects estimation procedure assumes that firm-specific effects are uncorrelated with the independent variables and is efficient under this assumption. If the assumption is violated, the random-effects estimator is biased while the fixed-effects estimator is still consistent. ${ }^{9}$ Therefore, Hausman specification tests have been conducted with the null hypothesis of the random-effects model being efficient (and consistent), The following cases have been tested: a) Model (4.3.4) against Model (4.3.2); b) Model (4.3.3) against Model (4.3.1); c) Model (4.4.4) against Model (4.4.2); and d) Model (4.4.3) against Model (4.4.1); in all cases the null hypotheses was rejected at the 1 percent confidence level. These test results are also confirmed by high correlations between the residuals and the dependent variable in the random-effects models estimated. Since the random effects models might not be consistent, the results with respect to the influence of other factors besides volatility of returns might be considered not fully conclusive. However, also all fixed effects estimations presented indicate that the volatility of returns is the major determinant of profits.

\footnotetext{
${ }^{9}$ See, e.g., Greene (2002), Hausman (1978).
} 
Models (4.3.1) and (4.3.3) present a random effects and a fixed effects specification, respectively, with a large number of significant factors. Besides volatility (std3rshf), the year of incorporation (yearinc), six country dummies, the independence indicator, the activity indicator (i.e. the firm is still operating at the time of the last data update), four functional indicators, and five macroeconomic indicators are significant in the random effects specification. While these modes explains about 54 percent of profits, dropping all but the volatility variable does not seem to reduce the explanatory power of the model at all - Models (4.3.2) and (4.3.4) present a random effects and a fixed effects specification, respectively, with all variables but the constant and the volatility variable dropped - both models still explain about 54 percent of return on shareholder funds. Given the positive correlation between shareholder funds, total assets, and capital employed (see Table 3.2), these results are also true for return on capital measures using these other capital variables.

The results remain when endogeneity of the risk measure is taken into account. Table 4.4 presents four models where the volatility of the return on shareholder funds was instrumented with the volatility of the return on total assets. The results described already above are maintained when replacing the volatility variable of the return on shareholder funds with instruments. In fact, the explanatory power as measured by R-squared slightly increases relative to those of the RE/FE models. Parameter estimates indicate that the return on capital should increase by about 0.65 to 0.85 percentage points for every percentage point increase in risk measured as standard deviation. The results also seem to be robust with respect to different time periods chosen for the volatility measures. ${ }^{10}$

Similar estimations using returns on enterprise value (market value) of publicly listed firms lead to similar results, even with respect to ERP parameters obtained. With a data set of 3666 publicly listed firms and 12262 observations and using return on enterprise value as

\footnotetext{
${ }^{10}$ See Lutz/Kleinfeldt (2012)
} 
independent variable, OLS and instrumental variable regressions yield estimates for the ERP parameter of 0.74 to 0.79 . Following the CAPM theory, returns on equity include the market risk premium multiplied by the covariance of the returns on the equity invested with the market return. The covariance can be decomposed into the correlation coefficient between individual return and market return and the standard deviation of the individual return. However, the data on about 3600 publicly listed firms utilized here also provide evidence that the correlation coefficient between individual return and market return (e.g. S\&P 500 stock returns) does not have any significant impact on individual firm's returns while the standard deviation of the individual return on equity does seem to be a robust determinant of profits measured as returns.

\section{Conclusions}

For European publicly traded and privately held firms from all kinds of industries, the standard deviation of the individual return on firm equity does seem to be a robust determinant of profits measured as returns. Parameter estimates indicate that an equity risk premium can be measured as about one third of the standard deviation of the return to equity of any particular firm. While other factors may or may not be significant in determining profits, the overwhelming determining influence on profits is given by the volatility of the returns once capital employed is accounted for. This generally holds true for multi-national enterprises and independent enterprises alike.

These findings have important implications for international transfer pricing. For the purpose of national taxation of MNEs transfer pricing is utilized in order to determine the taxable profit of a national subsidiary by comparing its profits to profits of hypothetically comparable independent firms. In many cases this is done by using profit-level indicators such as sales margins or cost margins that are not necessarily closely correlated to the capital employed in the 
operation of the particular firm. The research presented here implies that a return on capital measure might be the better profit level indicator to be used in many cases where this is so far not traditionally done.

Transfer pricing also often entails the valuation of firms, functional parts of firms, or individual assets within firms that are subsidiaries of an MNE, in particular in post-restructuring scenarios where the underlying risk profile of some or all of these firms, functions or assets within an MNE may change. Since the DCF method is applicable in many of these cases, the findings presented bear directly on the resulting valuations through their effect on applicable discount rates and on how to calculate adjustments for changes in risk profiles.

Further research will include analyzing data from non-European and in particular NorthAmerican firms; preliminary investigations indicate that the results will also hold for North American firms. Other open questions include the further exploration of the role of the correlation with the market return as well as the significance of systematic differences in returns between subgroups of firms according to industries, time periods, independence, etc. 


\section{Literature}

Brealey, R., S. Myers and F. Allen (2006). Corporate Finance, $8^{\text {th }}$ ed. (McGraw-Hill, New York).

Damodaran, A. (2010), "Equity Risk Premiums (ERP): Determinants, Estimation and Implications - The 2010 Edition”, Stern School of Business, New York University.

Damodaran, A. (2008), "Equity Risk Premiums (ERP): Determinants, Estimation and Implications", Stern School of Business, New York University.

Fama, E. F. and K. R. French (2004). "The Capital Asset Pricing Model: Theory and Evidence", Journal of Economic Perspectives, 18(3), 25-46.

Fama, E. F. (1977). "Risk-adjusted Discount Rates and Capital Budgeting under Uncertainty", in: Journal of Financial Economics, 5, 3 - 24.

Greene, W.H. (2002). Econometric Analysis (5th Edition), Prentice Hall.

Hausman, J. A. (1978). „Specification Tests in Econometrics“, Econometrica, Vol. 46, No. 6.

Lintner, J. (1965). “The Valuation of Risk Assets and the Selection of Risky Investments in Stock Portfolios and Capital Budgets", Review of Economics and Statistics, 47, 13-37.

Luenberger, D. (1998). Investment Science (Oxford University Press, New York).

Lutz, S. and D. Kleinfeldt (2012). "Risk as determinant of income and cross-border pricing of multi-national enterprises", Journal of Microeconomics, 1, forthcoming July 2012.

Markowitz, H. (1959). Portfolio Selection: Efficient Diversification of Investments, Cowles Foundation, Monograph No. 16 (John Wiley \& Sons, Inc., New York).

Modigliani, F. and M. H. Miller (1958). "The Cost of Capital, Corporation Finance, and the Theory of Investment", American Economic Review, 48:3, 261-97. 
Mossin, J. (1966). “Equilibrium in a Capital Asset Market” Econometrica, 35, 768-83.

OECD (1995/2001/2010). „Transfer Pricing Guidelines for Multinational Enterprises and Tax Administrations“, published 22 July 2010.

Perold, A. F. (2004). “The Capital Asset Pricing Model”, Journal of Economic Perspectives, 18(3), 3-24.

Peter, S. (2008). Theoretische und empirische Analyse von Margenvergleichen zur Bestimmung und Überprüfung von Verrechnungspreisen (Freiburger Dissertationsreihe).

Sharpe, W. F. (1964). "Capital Asset Prices: A Theory of Market Equilibrium Under Conditions of Risk", Journal of Finance, 19, 425-42.

Treynor, J. L. (1962). “Toward a Theory of Market Value of Risky Assets”, unpublished manuscript. Final version in: Korajczyk, R. A. (ed.)(1999). (Asset Pricing and Portfolio Performance (Risk Books, London), 15-22. 


\section{Appendix}

Table 1. Data sources

\begin{tabular}{|c|c|c|c|c|}
\hline \# & Data type & Source & Downloaded / data & Date \\
\hline 1 & $\begin{array}{l}\text { Firm data } \\
\text { (balance } \\
\text { sheet, } \\
\text { profit/loss) }\end{array}$ & $\begin{array}{l}\text { Wharton } \\
\text { Research Data } \\
\text { Services (WRDS) } \\
{ }^{11} \text { : Bureau van } \\
\text { Dijk }\end{array}$ & $\frac{\text { https://wrds-web.wharton.upenn.edu/wrds/ }}{\text { (Data set: bvd/amadeus_l) }}$ & $\begin{array}{l}\text { 14 June } \\
2011\end{array}$ \\
\hline 2 & $\begin{array}{l}\text { Firm data } \\
\text { (descriptive) }\end{array}$ & Bureau van Dijk & $\begin{array}{l}\text { Amadeus "Very large, large and medium sized } \\
\text { companies" Blue-Ray disk }\end{array}$ & $\begin{array}{l}\text { Version } \\
\text { January } \\
2011\end{array}$ \\
\hline 3 & $\begin{array}{l}\text { Firm data } \\
\text { (publicly } \\
\text { quoted stock } \\
\text { data) }\end{array}$ & $\begin{array}{l}\text { WRDS: Thomson } \\
\text { Reuters }\end{array}$ & $\begin{array}{l}\text { https://wrds-web.wharton.upenn.edu/wrds/ } \\
\text { (Data set: tfn/s12type2, variables selected: CUSIP } \\
\text { EXCHCD FDATE INDCODE PRC SHROUT1 } \\
\text { SHROUT2 STKCD STKCDESC STKNAME } \\
\text { TICKER TICKER2) }\end{array}$ & $\begin{array}{l}8 \text { July } \\
2011\end{array}$ \\
\hline 4 & $\begin{array}{l}\text { European } \\
\text { economic } \\
\text { climate } \\
\text { index data }\end{array}$ & CESifo & $\begin{array}{l}\text { (http://www.cesifo-group.de/link/wes-zeitreihen- } \\
\text { euro-2009q4.xls } \\
\text { (Wirtschaftsklimaindikator Euroraum, Index R1) }\end{array}$ & $\begin{array}{l}\text { March } \\
2010\end{array}$ \\
\hline 5 & $\begin{array}{l}\text { Capacity } \\
\text { utilization } \\
\text { data }\end{array}$ & Bundesbank & $\begin{array}{l}\text { http://www.bundesbank.de/statistik/statistik zeitr } \\
\text { eihen.php?lang=de\&open=\&func=row\&tr=YJJW2 } \\
\text { 44 (series YJW244, capacity utilization in } \\
\text { manufacturing, Euro zone (16), in percent) }\end{array}$ & $\begin{array}{l}\text { March } \\
2010\end{array}$ \\
\hline 6 & $\begin{array}{l}\text { Industrial } \\
\text { production } \\
\text { index data }\end{array}$ & $\begin{array}{l}\text { European Central } \\
\text { Bank }\end{array}$ & $\begin{array}{l}\text { http://sdw.ecb.europa.eu/ } \\
\text { (Eurostat, Industrial Production Index, series } \\
\text { STS.M.I5.W.PROD.2C0000.4.000, } \\
\text { STS.M.I5.W.PROD.NS0040.4.000, and } \\
\text { STS.M.I5.W.PROD.NS0050.4.000, short-term } \\
\text { statistics, monthly, fixed composition, working- } \\
\text { day adjusted) }\end{array}$ & $\begin{array}{l}\text { March } \\
2010\end{array}$ \\
\hline 7 & $\begin{array}{l}\text { U.S. stocks } \\
\text { and bonds } \\
\text { data }\end{array}$ & $\begin{array}{l}\text { Damodaran, A., } \\
\text { Stern School of } \\
\text { Business, New } \\
\text { York University }\end{array}$ & $\begin{array}{l}\text { http://pages.stern.nyu.edu/ adamodar/pdfiles/pap } \\
\text { ers/ERP2011.pdf } \\
\text { (Appendix 1, annual returns on U.S. stocks (S\&P } \\
\text { 500, treasury bills ( } 6 \text { months) and treasury bonds } \\
(10 \text { years)) }\end{array}$ & $\begin{array}{l}\text { February } \\
2010\end{array}$ \\
\hline 8 & $\begin{array}{l}\text { European } \\
\text { stocks and } \\
\text { bonds data }\end{array}$ & Bloomberg & $\begin{array}{l}\text { Bloomberg Terminal } \\
\text { ( MSCI Europe Index MXEU PX_LAST, } \\
\text { Euro Generic Government Bond 3M } \\
\text { GECU3M Index PX_LAST) }\end{array}$ & $\begin{array}{l}17 \text { March } \\
2010\end{array}$ \\
\hline 9 & $\begin{array}{l}\text { European } \\
\text { longterm } \\
\text { bonds data }\end{array}$ & $\begin{array}{l}\text { European Central } \\
\text { Bank }\end{array}$ & $\begin{array}{l}\text { http://sdw.ecb.europa.eu/quickview.do?SERIES } \\
\text { KEY=143.FM.M.U2.EUR.4F.BB.U2 10Y.YLD } \\
\text { (Euro area 10-year Government Benchmark bond } \\
\text { yield - Euro } \\
\text { (FM.M.U2.EUR.4F.BB.U2 10Y.YLD)) }\end{array}$ & July 2011 \\
\hline
\end{tabular}

\footnotetext{
${ }^{11}$ Wharton Research Data Services (WRDS) was used in preparing part of the data set used in the research reported in this paper. This service and the data available thereon constitute valuable intellectual property and trade secrets of WRDS and/or its third-party suppliers.
} 


\section{Table 2. List of variables}

\begin{tabular}{|c|c|}
\hline Variable & Definition \\
\hline id_number & $\begin{array}{l}\text { BvD ID number (alphanumeric), Bureau van Dijk's } \\
\text { unique identification number for firms }\end{array}$ \\
\hline $\mathrm{BvD}$ & Firm ID number (numeric) \\
\hline Year & Year \\
\hline nacpri & NACE Rev.1.1 industry code \\
\hline nace2pri & NACE Rev. 2 industry code \\
\hline naicor & NAICS 2002 industry code \\
\hline yearinc & Year of incorporation \\
\hline opre & Operating revenue, EUR thousand \\
\hline gros & gross profit, EUR thousand \\
\hline ebit & EBIT, EUR thousand \\
\hline ebta & EBITDA, EUR thousand \\
\hline fipl & Financial profit/loss, EUR thousand \\
\hline taxa & Taxation, EUR thousand \\
\hline plat & Profit/loss after tax, EUR thousand \\
\hline $\mathrm{pl}$ & Profit/loss for the period, EUR thousand \\
\hline $\mathrm{cf}$ & Cash flow, EUR thousand \\
\hline av & Added value, EUR thousand \\
\hline toas & Total assets, EUR thousand \\
\hline tshf & Total shareholder funds and liabilities, EUR thousand \\
\hline solr & Solvency ratio $(\%)$ \\
\hline gear & Gearing ratio $(\%)$ \\
\hline enva / envainv & Enterprise value, EUR thousand / inverse of enva \\
\hline rshf & Return on shareholder funds (\%) \\
\hline rcem & Return on capital employed (\%) \\
\hline rtas & Return on total assets $(\%)$ \\
\hline RoEV & plat/enva \\
\hline rcfenva & cf/enva \\
\hline rprc & Percentage change of prc: (prc-1.prc)/l.prc \\
\hline sp500returns & S\&P 500 stock returns \\
\hline rmxeuye & Return on MSCI Europe Index year end \\
\hline IFO_eur & IFO index, economic climate, Euro zone \\
\hline Cap_Util_EWU & Capacity utilization, in percent, Euro zone (16) \\
\hline Prod_EWU_total & $\begin{array}{l}\text { Industrial production index (total manufacturing), } \\
\text { Euro zone (16) }\end{array}$ \\
\hline \multirow[t]{2}{*}{ Prod_EWU_IM } & $\begin{array}{l}\text { Industrial production index (intermediate goods), } \\
\text { Euro zone (16) }\end{array}$ \\
\hline & (to be continued) \\
\hline
\end{tabular}




\begin{tabular}{|c|c|}
\hline & Table 2. List of variables (continued) \\
\hline Variable & Definition \\
\hline Prod_EWU_Inv & $\begin{array}{l}\text { Industrial production index (investment goods), Euro } \\
\text { zone (16) }\end{array}$ \\
\hline Active & Dummy variable, by legal status \\
\hline Independence & $\begin{array}{l}\text { Dummy variable, if IndepA or IndepB or } \\
\text { ishdirect }<=25 \%\end{array}$ \\
\hline IndepA & Dummy variable, if $\mathrm{BvD}$ independence indicator $=\mathrm{A}^{*}$ \\
\hline IndepB & Dummy variable, if $\mathrm{BvD}$ independence indicator $=\mathrm{B}^{*}$ \\
\hline IndepU & Dummy variable, if BvD independence indicator $=\mathrm{U}$ \\
\hline Manufacturing & $\begin{array}{l}\text { Dummy variable; set to " } 1 \text { " if NACE } 1.1\left(10^{*}, 15^{*} \text {, }\right. \\
\left.17^{*}-35^{*}\right) \text {, NACE } 2\left(10^{*}-32^{*}\right) \text { or NAICS }\left(31^{*}-33^{*}\right) \\
\text { industry codes indicate manufacturing or if company } \\
\text { description (in trade description English, main activity } \\
\text { or secondary activity) contains at least one of the } \\
\text { terms manufact*, manufact*, producti*, Producti* }\end{array}$ \\
\hline Wholesale & $\begin{array}{l}\text { Dummy variable; set to " } 1 \text { " if NACE } 1.1\left(50^{*}-51^{*}\right) \text {, } \\
\text { NACE } 2\left(45^{*}-46^{*}\right) \text { or NAICS }\left(42^{*}\right) \text { industry codes } \\
\text { indicate wholesale or if company description (in trade } \\
\text { description English, main activity or secondary } \\
\text { activity) contains at least one of the terms Wholesal*, } \\
\text { wholesal*, whole sal*, Whole sal* }\end{array}$ \\
\hline Retail & $\begin{array}{l}\text { Dummy variable; set to "1" if NACE } 1.1\left(52^{*}\right) \text {, } \\
\text { NACE } 2\left(47^{*}\right) \text { or NAICS }\left(44^{*}-45^{*}\right) \text { industry codes } \\
\text { indicate retail or if company description (in trade } \\
\text { description English, main activity or secondary } \\
\text { activity) contains at least one of the terms Retail*, } \\
\text { retail*, end custom*, end consum* }\end{array}$ \\
\hline Service & $\begin{array}{l}\text { Dummy variable set to " } 1 \text { " if NACE } 1.1\left(25^{*}-37^{*} \text {, }\right. \\
\left.40^{*}-41^{*}, 90^{*}\right) \text {, NACE } 2\left(33^{*}-39^{*}\right) \text { or NAICS }\left(54^{*}-\right. \\
\left.56^{*}\right) \text { industry codes indicates service or repair or if } \\
\text { company description (in trade description English, } \\
\text { main activity or secondary activity) contains at least } \\
\text { one of the terms repair*, service*, traini*, consul* }\end{array}$ \\
\hline$<$ Country $>$ & Dummy variable, by $<$ Country $>$ \\
\hline IYear_<year $>$ & Dummy variable, by $<$ year $>$ \\
\hline consol_<\#> & $\begin{array}{l}\text { Dummy variables, by BvD consolidation code, } 1 \text { if } \\
\text { "C1",_2 if "C2",__3 if "LF",_4 if "U1", _5 if "U2" }\end{array}$ \\
\hline avg3rshf & $\begin{array}{l}\text { 3-period moving average of rshf } \\
(\mathrm{rshf}+1 . \mathrm{rshf}+12 . \mathrm{rshf}) / 3\end{array}$ \\
\hline $\operatorname{std} 3 \mathrm{rshf}$ & 3-period moving standard deviation of rshf \\
\hline avg3<var $>$ & 3-period moving average of $<$ var $>$ \\
\hline $\operatorname{std} 3<$ var $>$ & 3-period moving standard deviation of $<$ var $>$ \\
\hline
\end{tabular}


Table 3.1. Summary statistics (selected variables)

\begin{tabular}{|c|c|c|c|c|c|}
\hline Variable & Obs & Mean & Std. Dev. & Min & Max \\
\hline opre & 1857417 & $4.46 \mathrm{e}+07$ & $1.16 \mathrm{e}+08$ & 1 & $1.00 \mathrm{e}+09$ \\
\hline gros & 502733 & $1.21 \mathrm{e}+07$ & $3.75 \mathrm{e}+07$ & $-3.14 e+08$ & $1.00 \mathrm{e}+09$ \\
\hline ebit & 1984357 & 2955028 & $1.24 \mathrm{e}+07$ & $-4.51 e+08$ & $8.90 \mathrm{e}+08$ \\
\hline plat & 1967111 & 2608763 & $1.31 \mathrm{e}+07$ & $-3.77 e+08$ & $8.87 \mathrm{e}+08$ \\
\hline cf & 1597449 & 3307451 & $1.32 \mathrm{e}+07$ & $-4.26 e+08$ & $9.76 \mathrm{e}+08$ \\
\hline toas & 2001511 & $3.60 \mathrm{e}+07$ & $9.95 \mathrm{e}+07$ & -2631842 & $1.00 \mathrm{e}+09$ \\
\hline tshf & 2001510 & $3.60 \mathrm{e}+07$ & $9.95 e+07$ & -2631842 & $1.00 \mathrm{e}+09$ \\
\hline solr & 2001504 & 38.06282 & 26.40745 & 0 & 100 \\
\hline gear & 1858141 & 217.0071 & 665.6041 & 0 & 10000 \\
\hline enva & 36067 & 3530902 & $3.37 \mathrm{e}+07$ & $-1.73 e+07$ & $2.15 \mathrm{e}+09$ \\
\hline rshf & 2001878 & 41.76233 & 71.15785 & .01 & 1000 \\
\hline rcem & 1572933 & 31.40639 & 52.79459 & -310.81 & 1000 \\
\hline rtas & 2001501 & 9.791261 & 11.72182 & -7.52 & 100 \\
\hline RoEV & 24492 & 1.157682 & 190.2881 & -9304.3 & 23751.1 \\
\hline Active & 1979288 & .8451792 & .3617339 & 0 & 1 \\
\hline Independence & 1739458 & .2436805 & .4293022 & 0 & 1 \\
\hline Manufacturing & 1731265 & .2590609 & .4381192 & 0 & 1 \\
\hline Wholesale & 1712041 & .2258316 & .4181289 & 0 & 1 \\
\hline Retail & 1664248 & .0686292 & .2528226 & 0 & 1 \\
\hline Services & 1770994 & .3364811 & .4725058 & 0 & 1 \\
\hline France & 1644267 & .1438647 & .3509526 & 0 & 1 \\
\hline Germany & 1644267 & .0690946 & .253615 & 0 & 1 \\
\hline Italy & 1644267 & .151147 & .3581922 & 0 & 1 \\
\hline Russia & 1644267 & .0800284 & .2713372 & 0 & 1 \\
\hline Spain & 1644267 & .1316635 & .3381247 & 0 & 1 \\
\hline UK & 1644267 & .0664862 & .2491301 & 0 & 1 \\
\hline _IYear_2000 & 2001878 & .0671474 & .2502772 & 0 & 1 \\
\hline _IYear_2001 & 2001878 & .0754317 & .2640867 & 0 & 1 \\
\hline _IYear_2002 & 2001878 & .0816803 & .2738771 & 0 & 1 \\
\hline _IYear_2003 & 2001878 & .0879504 & .2832228 & 0 & 1 \\
\hline _IYear_2004 & 2001878 & .0994546 & .2992715 & 0 & 1 \\
\hline _IYear_2005 & 2001878 & .1143916 & .3182864 & 0 & 1 \\
\hline _IYear_2006 & 2001878 & .1270677 & .3330489 & 0 & 1 \\
\hline _IYear_2007 & 2001878 & .1310849 & .3374933 & 0 & 1 \\
\hline _IYear_2008 & 2001878 & .117157 & .3216073 & 0 & 1 \\
\hline _IYear_2009 & 2001878 & .0519507 & .2219276 & 0 & 1 \\
\hline
\end{tabular}


Table 3.2. Correlations profit and return-on-capital variables

\begin{tabular}{|l|l|l|l|l|l|l|}
\hline & plbt & cf & gros & fipl & plat & pl \\
\hline & & & & & & \\
\hline plbt & 1.0000 & & & & & \\
\hline cf & 0.9035 & 1.0000 & & & & \\
\hline gros & 0.6144 & 0.6333 & 1.0000 & & & \\
\hline fipl & 0.5828 & 0.4200 & -0.0439 & 1.0000 & & \\
\hline plat & 0.9813 & 0.8965 & 0.5773 & 0.6393 & 1.0000 & \\
\hline pl & 0.9373 & 0.9403 & 0.5324 & 0.6285 & 0.9472 & 1.0000 \\
\hline av & 0.7139 & 0.7855 & 0.8479 & 0.1486 & 0.6601 & 0.6688 \\
\hline ebit & 0.7542 & 0.7584 & 0.7041 & -0.0678 & 0.6884 & 0.6527 \\
\hline ebta & 0.7761 & 0.8174 & 0.7517 & -0.0832 & 0.7123 & 0.6772 \\
\hline
\end{tabular}

\begin{tabular}{|l|l|l|l|}
\hline & av & ebit & ebta \\
\hline & & & \\
\hline av & 1.0000 & & \\
\hline ebit & 0.7112 & 1.0000 & \\
\hline ebta & 0.7834 & 0.9515 & 1.0000 \\
\hline
\end{tabular}

\begin{tabular}{|l|l|l|l|l|l|l|}
\hline & rshf & rcem & rtas & RoEV & rcfenva & rprc \\
\hline & & & & & & \\
\hline rshf & 1.0000 & & & & & \\
\hline rcem & 0.5951 & 1.0000 & & & & \\
\hline rtas & 0.3367 & 0.3395 & 1.0000 & & & \\
\hline RoEV & 0.0054 & 0.0116 & 0.0272 & 1.0000 & & \\
\hline rcfenva & 0.0057 & 0.0142 & 0.0304 & 0.9988 & 1.0000 & \\
\hline rprc & 0.0124 & 0.0209 & 0.0262 & -0.0196 & 0.0010 & 1.0000 \\
\hline
\end{tabular}


Table 4.1. Results summary: pooled regressions

\begin{tabular}{|l|c|c|c|c|}
\hline \multicolumn{1}{|c|}{ Model } & $\mathbf{( 4 . 1 . 1 )}$ & $\mathbf{( 4 . 1 . 2 )}$ & $\mathbf{( 4 . 1 . 3 )}$ & $\mathbf{( 4 . 1 . 4 )}$ \\
\hline Dep. Variable & avg3cf & avg3cf & avg3rshf & avg3rtas \\
\hline & & & & \\
\hline std3cf & $1.045481^{* * *}$ & $1.058874^{* * *}$ & $1.136805^{* * *}$ & $1.139074^{* * *}$ \\
\hline nacpri & & $-137.386^{* * *}$ & & \\
\hline & & & & 1106443 \\
\hline Observations & 893828 & 812513 & 1106659 & 0.3551 \\
\hline R-sq. overall & 0.5037 & 0.5041 & 0.5472 & 0.0000 \\
\hline Prob > F & 0.0000 & 0.0000 & 0.0000 & \\
\hline & & & & \\
\hline
\end{tabular}

Notes. (i) All models pooled OLS regressions. (ii) All equations include a constant. (iii) $* * *$ denotes significant at the $1 \%, * *$ at the $5 \%, *$ at the $10 \%$ level. 
Table 4.2. Results summary: cash flows - OLS, RE, and FE models

\begin{tabular}{|c|c|c|c|c|}
\hline Model & (4.2.1) OLS & (4.2.2) fixed effects & $(4.2 .3)$ OLS & $(4.2 .4)$ \\
\hline Dep. Variable & avg3cf & avg3cf & avg3cf & avg3cf \\
\hline std3cf & $0.799987 * * *$ & $0.6610282 * * *$ & $0.749758 * * *$ & $0.7563756^{* * *}$ \\
\hline envainv & & 7332.907 & -2243517 & \\
\hline Spain & $5853797 * * *$ & & & \\
\hline Italy & $1426864 * *$ & & & \\
\hline Active & $1892837 * *$ & & & \\
\hline IndepA & $-1658463 * * *$ & & & \\
\hline IndepB & $-1173539 * *$ & & & \\
\hline Wholesale & $-2735592 * * *$ & & & \\
\hline Services & $-1717542 * * *$ & & & \\
\hline opre & $0.068184 * * *$ & $0.0983477 * * *$ & & \\
\hline gear & $-3938.29 * * *$ & 46.94495 & & \\
\hline Observations & 4116 & 13596 & 13717 & 893828 \\
\hline Groups (Firms) & & 3515 & & 205162 \\
\hline R-sq. within & & 0.6436 & & 0.3384 \\
\hline R-sq. between & & 0.9318 & & 0.5984 \\
\hline R-sq. overall & 0.6709 & 0.8379 & 0.8135 & 0.5037 \\
\hline Prob > chi2 & 0.000 & 0.000 & 0.000 & 0.000 \\
\hline
\end{tabular}

Notes.

(i) Models (1), (3) pooled OLS regression; model (2) fixed effects; model (4) random effects. (ii) All equations include a constant.

(iii) $* * *$ denotes significant at the $1 \%, * *$ at the $5 \%, *$ at the $10 \%$ level.

(iv) Model (1) variables not significant: UK, Germany, France, IndepU, Manufacturing, Retail, sp500returns, IFO_eur, Cap_Util_EWU, Prod_EWU_total, Prod_EWU_IM, Prod_EWU_Inv, rmxeuye, empl, Year2; variables dropped: ResDev, Venture, Equity, USTBills6m, USTBonds10y, rmxeu, std3spsr, Year. 
Table 4.3. Results summary: return on shareholder funds - RE/FE models

\begin{tabular}{|c|c|c|c|c|}
\hline Model & (4.3.1) & (4.3.2) & (4.3.3) fixed effects & (4.3.4) fixed effects \\
\hline Dep. Variable & avg3rshf & avg3rshf & avg3rshf & avg3rshf \\
\hline std3rshf & $0.789972 * * *$ & $0.806578 * * *$ & $0.7140072 * * *$ & $0.720763 * * *$ \\
\hline yearinc & $0.229054 * * *$ & & & \\
\hline France & $3.070362 * * *$ & & & \\
\hline Germany & $11.43738 * * *$ & & & \\
\hline Italy & $2.736591 * * *$ & & & \\
\hline Russia & $18.16991 * * *$ & & & \\
\hline Spain & $-5.99855 * * *$ & & & \\
\hline UK & $-3.00243 * * *$ & & & \\
\hline Active & $-0.91335^{* *}$ & & & \\
\hline Independence & $-1.29535 * * *$ & & & \\
\hline Manufacturing & $-3.495088 * * *$ & & & \\
\hline Wholesale & $4.433904 * * *$ & & & \\
\hline Services & $3.280111 * * *$ & & & \\
\hline Retail & $9.629188 * * *$ & & & \\
\hline sp500returns & -0.37401 & & 0.184767 & \\
\hline rmxeuye & -0.20085 & & $-0.707123 * * *$ & \\
\hline IFO_eur & $0.025293 * * *$ & & $0.037921 * * *$ & \\
\hline Cap_Util_EWU & $1.357804^{* * *}$ & & $1.540853 * * *$ & \\
\hline Prod_EWU_total & $2.660906^{* * *}$ & & $2.026211 * * *$ & \\
\hline Prod_EWU_IM & $-1.8694 * * *$ & & $-1.708258 * * *$ & \\
\hline Prod_EWU_Inv & $-0.96745 * * *$ & & $-0.728277 * * *$ & \\
\hline Observations & 780592 & 1106659 & 1089941 & 1106659 \\
\hline Groups (Firms) & 174667 & 257697 & 256407 & 257697 \\
\hline R-sq. within & 0.4327 & 0.4407 & 0.4430 & 0.4407 \\
\hline R-sq. between & 0.5990 & 0.6115 & 0.6065 & 0.6115 \\
\hline R-sq. overall & 0.5328 & 0.5472 & 0.5434 & 0.5472 \\
\hline Prob > chi2 (>F) & 0.0000 & 0.0000 & 0.0000 & 0.0000 \\
\hline
\end{tabular}

Notes. (i) Models (1) and (2) estimated with random effects; Models (3) and (4) estimated with fixed effects. (ii) All equations include a constant. (iii) $* * *$ denotes significant at the $1 \%, * *$ at the $5 \%, *$ at the $10 \%$ level. 
Table 4.4. Results summary: return on shareholder funds - IV models

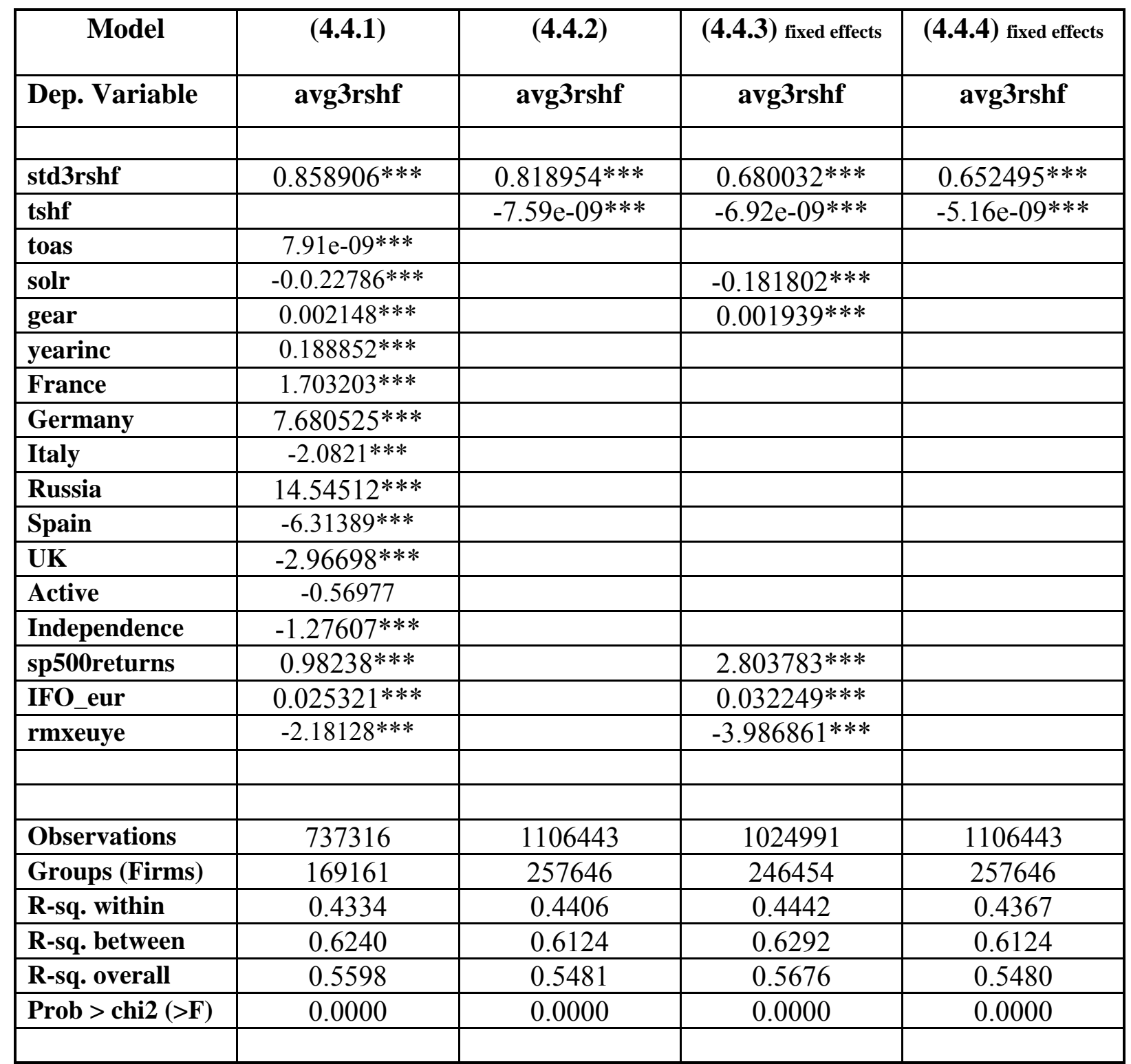

Notes. (i) Models (1) and (2) estimated with random effects; Models (3) and (4) estimated with fixed effects. All models IV regressions with std3rshf instrumented by std3rtas and other variables. (ii) All equations include a constant. (iii) $* * *$ denotes significant at the $1 \%, * *$ at the $5 \%$, * at the $10 \%$ level. 